\title{
ФЕНОМЕНОЛОГІЧНА ТЕОРІЯ ПЕРЕРИВЧАСТОГО РЕЖИМУ МЕЖОВОГО ТЕРТЯ
}

\author{
Я.О. ЛЯШЕНКО, ${ }^{1}$ О.в. ХОМЕНКО, ${ }^{1}$ Л.С. МЕТЛОВ ${ }^{2}$ \\ ${ }^{1}$ Сумський державний університет \\ (Вул. Римсъкого-Корсакова, 2, Суми 40007; e-mail: nabla04@ukr. net, khom@mss. sumdu. edu. иа) \\ 2 Донецький фізико-технічний інститут ім. О.О. Галкіна НАН України \\ (Вул. Рози Люксембура, 72, Донецък 83114; e-mail: lsmet@fti.dn.ua)
}

УдК 539.2:621.891

Побудовано детерміністичну теорію плавлення ультратонкої плівки мастила, яку затиснуто між двома атомарно-гладкими твердими поверхнями. Для опису стану мастила введено параметр надлишкового об'єму, що виникає за рахунок хаотизації структури твердого тіла у процесі плавлення. Узгоджено описано термодинамічне і зсувне плавлення. Проаналізовано залежності стаціонарної сили тертя від температури мастила i швидкості зсуву поверхонь, що труться, при їх рівномірному зсуві зі сталою швидкістю. У межах простої трибологічної моделі описано переривчастий режим тертя, при якому мастило періодично плавиться і твердне. Проаналізовано вплив швидкості, температури i навантаження на переривчасте тертя. Проведено якісне порівняння отриманих результатів із експериментальними даними.

\section{1. ВСТУП}

При товщині змащувального матеріалу, меншій за 10 атомарних шарів, виникає режим межового тертя [1]. Експерименти показують, що такий тонкий шар мастила проявляє аномальні властивості в порівнянні з об'ємними рідинами, або із мастилами, товщина яких більша лише у декілька разів [2]. Зокрема спостерігається властивий сухому тертю переривчастий рух (stick-slip) [2,3]. Такий режим пояснюється як тверднення, що зумовлене стисканням поверхонь, що труться, і подальше стрибкоподібне плавлення при перевищенні зсувними напруженнями межі текучості ("зсувне плавлення").

Існує декілька феноменологічних моделей, що дозволяють частково пояснити експериментально спостережувані результати. Наприклад, такі як термодинамічні $[4,5]$, механістична [6] і синергетична $[7,8]$.
Вони мають як детерміністичну [5-7], так і стохастичну [9-11] природу. Дослідження також проводяться за допомогою методів молекулярної динаміки [12-14]. Виявляється, що мастило може забезпечувати кілька кінетичних режимів, між якими у процесі тертя відбуваються переходи, що приводять до переривчастого руху [2]. У теоретичній роботі [9] знайдено три режими тертя: режим ковзання при малих швидкостях зсуву, регулярний переривчастий режим і режим ковзання при великих швидкостях зсуву. Існування цих режимів підтверджують численні експерименти $[1-3,15]$.

$\mathrm{У}$ роботах $[7,8]$ в рамках моделі Лоренца для апроксимації в'язкопружного середовища розвинено підхід, згідно з яким перехід ультратонкої плівки мастила 3 твердоподібного в рідиноподібний стан відбувається в результаті термодинамічного і зсувного плавлення. Проведено опис цих процесів, що відбуваються в результаті самоорганізації полів зсувних напружень і деформації, а також температури мастила з урахуванням адитивних шумів вказаних величин $[16,17]$ та корельованих флуктуацій температури [18]. Показано, що у випадку адитивних шумів встановлюється самоподібний режим плавлення мастила, у якому часові ряди напружень набувають мультифрактальних властивостей $[19,20]$. Причини стрибкоподібного плавлення і гістерезису, які спостерігалися в експериментах [21-23], розглянуто в роботах [24-26]. Тут також визначено умови реалізації означених особливостей при врахуванні деформаційного дефекту модуля зсуву. У межах вказаної моделі також описано періодичний переривчастий режим тертя [11, 27], який, проте, має стохастичну складову, і може реалі- 
зовуватися тільки за наявності у системі флуктуацій. Ще одним недоліком вказаної моделі $є$ те, що вона не враховує навантаження, яке прикладено до поверхонь тертя і при отриманні основних рівнянь застосовано низку наближень [7].

У роботі [5] запропоновано термодинамічну теорію, що заснована на розкладанні вільної енергії системи за степенями параметра $f$, який є надлишковим об'ємом $[28,29]$, що виникає в результаті формування дефектної структури в мастилі при його плавленні. Рідиноподібний стан інтерпретується як ділянка пластичної течії на діаграмі навантаження і характеризується наявністю в мастилі дефектів [4]. У роботі [5] для опису сильно нерівноважних процесів, що відбуваються при ковзанні двох твердих тіл, що труться та розділені шаром мастила, використовується підхід, заснований на теорії фазових переходів Ландау [3034]. Однак роботу [5] присвячено дослідженню плавлення мастила при зсуві поверхонь тертя із сталою швидкістю та вона не описує переривчастого режиму руху, що спостерігається в експериментах [2]. Запропонована робота $\epsilon$ продовженням розгляду [5] та іï метою є дослідження періодичного режиму переривчастого тертя у рамках механічного еквівалента трибологічної системи, оскільки численні експерименти вказують саме на періодичний характер переривчастого руху [2].

\section{2. Основні рівняння}

При плавленні мастила, товщиною менше ніж 10 молекулярних шарів, стаціонарні стани, в яких воно знаходиться, не є термодинамічними фазами, а подають кінетичні режими тертя, яких може бути декілька. При цьому говорять не про тверду і рідку, а про твердоподібну і рідиноподібну фази. Про плавлення таких мастил судять по збільшенню їх об'єму [12] і коефіцієнта дифузії $[12,13,35,36]$. Оскільки експериментально спостережуваною величиною з зазначених двох $\epsilon$ об'єм, для опису стану мастила введемо параметр $f$, який має фізичний сенс надлишкового об'єму [28, 29], що виникає за рахунок хаотизації структури твердого тіла у процесі плавлення. Зі зростанням параметра $f$ росте густина дефектів в мастилі, яке за рахунок їх транспортування, що відбувається під дією прикладеного дотичного напруження, переходить в кінетичний режим пластичної течії (рідиноподібна фаза).

Запишемо розкладання для густини вільної енергії з урахуванням внесків від пружних компонент зсув- них деформацій $\varepsilon_{i j}^{\mathrm{e}}$ та ентропії $s$ у вигляді [5]:

$\Phi=\Phi_{0}^{*}+\frac{1}{2} \lambda\left(\varepsilon_{i i}^{\mathrm{e}}\right)^{2}+\mu\left(\varepsilon_{i j}^{\mathrm{e}}\right)^{2}-\alpha s^{2}+\frac{c}{2}(\nabla f)^{2}-$

$-\varphi_{0} f+\frac{1}{2} \varphi_{1} f^{2}-\frac{1}{3} \varphi_{2} f^{3}+\frac{1}{4} \varphi_{3} f^{4}$

де $\Phi_{0}^{*}, \lambda, \mu, \alpha, c, \varphi_{0}, \varphi_{1}, \varphi_{2}, \varphi_{3}$ - константи розкладання. Причому, у свою чергу,

$\varphi_{0}=\varphi_{0}^{*}+\frac{1}{2} \bar{\lambda}\left(\varepsilon_{i i}^{\mathrm{e}}\right)^{2}+\bar{\mu}\left(\varepsilon_{i j}^{\mathrm{e}}\right)^{2}+\alpha_{\varphi} s$.

Пружні напруження враховуються з точністю до квадратичних внесків через інваріанти тензора деформацій $\varepsilon_{i i}^{\mathrm{e}},\left(\varepsilon_{i j}^{\mathrm{e}}\right)^{2}=\varepsilon_{i j}^{\mathrm{e}} \varepsilon_{j i}^{\mathrm{e}}$, де під індексами, що повторюються, мається на увазі підсумовування. При цьому перший інваріант подає слід тензора деформацій $\varepsilon_{i i}^{\mathrm{e}}=\varepsilon_{1}^{\mathrm{e}}+\varepsilon_{2}^{\mathrm{e}}+\varepsilon_{3}^{\mathrm{e}}$, а другий визначається виразом [37]:

$\left(\varepsilon_{i j}^{\mathrm{e}}\right)^{2} \equiv\left(\varepsilon_{l l}^{\mathrm{e}}\right)^{2}-2 I_{2}=\left(\varepsilon_{1}^{\mathrm{e}}+\varepsilon_{2}^{\mathrm{e}}+\varepsilon_{3}^{\mathrm{e}}\right)^{2}-$

$-2\left(\varepsilon_{1}^{\mathrm{e}} \varepsilon_{2}^{\mathrm{e}}+\varepsilon_{1}^{\mathrm{e}} \varepsilon_{3}^{\mathrm{e}}+\varepsilon_{2}^{\mathrm{e}} \varepsilon_{3}^{\mathrm{e}}\right)=\left(\varepsilon_{1}^{\mathrm{e}}\right)^{2}+\left(\varepsilon_{2}^{\mathrm{e}}\right)^{2}+\left(\varepsilon_{3}^{\mathrm{e}}\right)^{2}$.

Згідно з виразом (1) в мастилі виникають пружні напруження

$\sigma_{i j}^{\mathrm{e}}=\frac{\partial \Phi}{\partial \varepsilon_{i j}^{\mathrm{e}}}=\lambda \varepsilon_{i i}^{\mathrm{e}} \delta_{i j}+2 \mu \varepsilon_{i j}^{\mathrm{e}}-\left(\bar{\lambda} \varepsilon_{i i}^{\mathrm{e}} \delta_{i j}+2 \bar{\mu} \varepsilon_{i j}^{\mathrm{e}}\right) f$.

Вираз (4) можна подати у вигляді ефективного закону Гука:

$\sigma_{i j}^{\mathrm{e}}=2 \mu_{\mathrm{eff}} \varepsilon_{i j}^{\mathrm{e}}+\lambda_{\mathrm{eff}} \varepsilon_{i i}^{\mathrm{e}} \delta_{i j}$

з ефективними пружними параметрами ${ }^{1}$

$\mu_{\mathrm{eff}}=\mu-\bar{\mu} f$

$\lambda_{\mathrm{eff}}=\lambda-\bar{\lambda} f$

які зменшуються з плавленням при зростанні параметра $f$.

Нескладно показати, що інваріанти визначаються яK

$\varepsilon_{i i}^{\mathrm{e}}=\frac{n}{\lambda_{\mathrm{eff}}+\mu_{\mathrm{eff}}}$

${ }^{1}$ При $f>\mu / \bar{\mu}$ слід вважати $\mu_{\text {eff }}=0$, а коли $f>\lambda / \bar{\lambda}$, необхідно приймати $\lambda_{\text {eff }}=0$. 
$\left(\varepsilon_{i j}^{\mathrm{e}}\right)^{2}=\frac{1}{2}\left[\left(\frac{\tau}{\mu_{\mathrm{eff}}}\right)^{2}+\left(\varepsilon_{i i}^{\mathrm{e}}\right)^{2}\right]$,

де $n, \tau$ - нормальна і дотична (зсувна) компоненти напружень, які діють на мастило з боку поверхонь, що труться ${ }^{2}$. Співвідношення (8) та (9) подають зв'язок між компонентами тензорів і їх інваріантами лінійної теорії пружності [37].

Запишемо еволюційне рівняння для нерівноважного параметра $f$ у вигляді рівняння ЛандауХалатнікова:

$\tau_{f} \dot{f}=-\frac{\partial \Phi}{\partial f}$

де введено час релаксації $\tau_{f}$. У явному вигляді воно запишеться як

$\tau_{f} \frac{\partial f}{\partial t}=-c \nabla^{2} f+\varphi_{0}-\varphi_{1} f+\varphi_{2} f^{2}-\varphi_{3} f^{3}-\frac{n^{2}(\bar{\lambda}+\bar{\mu})}{\left(\lambda_{\mathrm{eff}}+\mu_{\mathrm{eff}}\right)^{2}}$,

де поява останнього доданка пов'язана з тим, що інваріанти (8) і (9) залежать від величини надлишкового об'єму $f$. У [5] цим доданком нехтували, однак його врахування важливе, оскільки здатне описати вплив зовнішнього тиску на процес плавлення.

Температура мастила визначається через вільну енергію системи:

$T=-\frac{\partial \Phi}{\partial s}=2 \alpha s+\alpha_{\varphi} f$

Таким чином, ентропія $є$ функцією температури і надлишкового об'єму. При цьому вільна енергія (1) також є функцією температури та об'єму.

Для опису процесів теплообміну мастила 3 навколишнім середовищем введемо температуру поверхонь тертя $T_{e}[7]$. У випадку неоднорідного нагріву середовища рівняння теплопровідності є звичайним рівнянням безперервності [38]:

$T \frac{\partial s}{\partial t}=\kappa \nabla^{2} T$

де коефіцієнт теплопровідності $\kappa$ вважається сталим. Для нормальної складової $\nabla_{z}^{2}$ з достатньою точністю можна використовувати наближення $\kappa \nabla_{z}^{2} T \approx$

2 Зсувні напруження $\tau$ визначаються із виразу (5) при $i \neq j$, тобто при $\delta_{i j}=0$. У випадку $\mu_{\text {eff }}=0$ доданок $\tau / \mu_{\text {eff в }}(9)$ слід замінювати відповідно до $(5)$ на $2 \varepsilon_{i j}^{\mathrm{e}}$. $\left(\kappa / h^{2}\right)\left(T_{e}-T\right)$, де $h$ - товщина мастила. Із врахуванням цього рівняння (13) записуємо у вигляді

$\frac{\partial s}{\partial t}=\frac{\kappa}{h^{2}}\left(\frac{T_{e}}{T}-1\right)+\frac{\kappa}{T} \nabla_{x y}^{2} T$

де величина $h^{2} / \kappa$ відіграє роль часу релаксації, протягом якого відбувається вирівнювання температур по товщині мастила за рахунок теплопровідності.

Використаємо дебаївське наближення, що зв'язує пружну деформацію $\varepsilon_{i j}^{\mathrm{e}} 3$ пластичною $\varepsilon_{i j}^{\mathrm{pl}}[4]$ :

$\dot{\varepsilon}_{i j}^{\mathrm{pl}}=\frac{\varepsilon_{i j}^{\mathrm{e}}}{\tau_{\varepsilon}}$,

де $\tau_{\varepsilon}$ - максвеллівський час релаксації внутрішніх напружень. Повна деформація в шарі визначається як

$\varepsilon_{i j}=\varepsilon_{i j}^{\mathrm{e}}+\varepsilon_{i j}^{\mathrm{pl}}$.

Ця деформація задає швидкість руху верхнього блока $V_{i j}$ згідно з наступним зв'язком [39]:

$V_{i j}=h \dot{\varepsilon}_{i j}=h\left(\dot{\varepsilon}_{i j}^{\mathrm{e}}+\dot{\varepsilon}_{i j}^{\mathrm{pl}}\right)$.

3 трьох останніх співвідношень випливає вираз для пружної компоненти зсувної деформації [5]:

$\tau_{\varepsilon} \dot{\varepsilon}_{i j}^{\mathrm{e}}=-\varepsilon_{i j}^{\mathrm{e}}+\frac{V_{i j} \tau_{\varepsilon}}{h}$.

Далі, в межах цієї роботи, для спрощення розглядається однорідна система, і в співвідношеннях (1), (11), (14) вважається $\nabla \equiv 0$.

\section{3. Сила тертя}

Система кінетичних рівнянь (11), (14), (18) з урахуванням визначень $(2),(5)-(9),(12)$ є замкненою і може бути використана для дослідження кінетики процесу плавлення. У даному розділі розглянемо стаціонарні режими тертя. Відповідно до рівнянь (14) і (18) 3 часом встановлюються стаціонарні значення температури мастила $T_{0}$ i пружної компоненти зсувної деформації $\varepsilon_{i j 0}^{\mathrm{e}}$ :

$T_{0}=T_{e}, \quad \varepsilon_{i j 0}^{\mathrm{e}}=\frac{V_{i j} \tau_{\varepsilon}}{h}$.

Для знаходження стаціонарних станів всіх величин необхідно чисельно розв'язати еволюційне рівняння (11), використовуючи (2), (5) - (9) і визначаючи поточну ентропію з (12) при $T=T_{e}$, а значення деформації з (19). 
У експериментальних роботах часто наводяться залежності сили тертя від швидкості зсуву, товщини шарів мастил, нормального тиску [1-3, 21-23]. У цьому розділі проаналізуємо вплив на силу тертя температури мастила і швидкості зсуву.

У мастилі, крім пружних $\sigma_{i j}^{\mathrm{e}}$, виникають також $\mathrm{i}$ в'язкі $\sigma_{i j}^{\text {visc }}$ напруження. Повне напруження в шарі $\epsilon$ сумою цих двох внесків:

$\sigma_{i j}=\sigma_{i j}^{\mathrm{e}}+\sigma_{i j}^{\mathrm{visc}}$.

Повна сила тертя визначається стандартно:

$F_{i j}=\sigma_{i j} A$,

де $A$ - площа контактуючих поверхонь. В'язкі напруження в шарі подано формулою [39]:

$\sigma_{i j}^{\text {visc }}=\frac{\eta_{\text {eff }} V_{i j}}{h}$

де $\eta_{\text {eff }}$ - ефективна в'язкість, яка знаходиться тільки експериментально і в межовому режимі $[39,40]$ :

$\eta_{\text {eff }} \sim\left(\dot{\varepsilon}_{i j}\right)^{\gamma}$

де $\gamma<0$ для псевдопластичних мастил та $\gamma>0$ для ділатантних [40]. 3 урахуванням (17), (23) вираз для в'язких напружень (22) записано у вигляді

$\sigma_{i j}^{\mathrm{visc}}=\left(\frac{V_{i j}}{h}\right)^{\gamma+1}$.

Після підстановки (20) i (24) в (21) маємо шуканий вираз для сили тертя $[5]^{3}$ :

$F_{i j}=\left[\sigma_{i j}^{\mathrm{e}}+\operatorname{sgn}\left(V_{i j}\right)\left(\frac{\left|V_{i j}\right|}{h}\right)^{\gamma+1}\right] A$,

де $\sigma_{i j}^{\mathrm{e}}$ задається формулою (5) при $i \neq j$.

В експериментах у ролі поверхонь тертя зазвичай використовуються атомарно-гладкі поверхні слюди, а в ролі мастила - квазісферичні молекули октаметілциклотетрасілоксана (ОМЦТС) і лінійні ланцюгові молекули тетрадекана або гексадекана [2, 23]. Вказані експерименти проводяться за таких умов: товщина мастила $h \sim 10^{-9}$ м, площа контакту $A \sim 3 \cdot 10^{-9} \mathrm{M}^{2}$, навантаження на верхню поверхню тертя $L=(2-$ $60) \cdot 10^{-3} \mathrm{H}$, що відповідає нормальним напруженням $n=-L / A=-(6,67-200) \cdot 10^{5}$ Па. Сила тертя при

3 Тут введено знакову функцію $\operatorname{sgn}(\mathrm{x})$ i абсолютне значення швидкості зсуву $\left|V_{i j}\right|$, оскільки вона може приймати також i від'ємні значення. цьому становить $F \sim(2-40) \cdot 10^{-3}$ Н. В межах зазначених експериментальних робіт виявлено, що мастило плавиться при перевищенні критичного значення температури $T_{e}>T_{c 0} \sim 300 \mathrm{~K}$ або при швидкості зсуву $V>V_{c} \sim 400 \mathrm{Hм} /$ с. Ці значення можуть істотно змінюватися залежно від типу мастила і геометрії експерименту.

У даній моделі, відповідно до експериментальних даних, вибираються такі значення констант теорії [5]: $\Phi_{0}^{*}=20$ Дж $/ \mathrm{m}^{3}, \lambda=2 \cdot 10^{11} \Pi \mathrm{a}, \bar{\lambda}=10^{8} \Pi \mathrm{\Pi}$, $\mu=4,1 \cdot 10^{11} \Pi \mathrm{a}, \bar{\mu}=4 \cdot 10^{11} \Pi \mathrm{a}, \varphi_{0}^{*}=5$ Дж $/ \mathrm{m}^{3}, \varphi_{1}=$ 1100 Дж $/ \mathrm{m}^{3}, \varphi_{2}=2700$ Дж $/ \mathrm{m}^{3}, \varphi_{3}=2070$ Дж $/ \mathrm{m}^{3}$, $\alpha=0,055 \mathrm{~K}^{2} \cdot \mathrm{m}^{3} /$ Дж, $\alpha_{\varphi}=0,05 \mathrm{~K}, h=10^{-9} \mathrm{M}$, $\tau_{f}=1$ Па.с, $\tau_{\varepsilon}=10^{-8}$ с. Зазначимо, що час релаксації надлишкового об'єму $\tau_{f}$ має розмірність в'язкості. Фактично це означає, що зі зростанням ефективної в'язкості мастила час встановлення стаціонарного режиму тертя збільшується.

Залежність (25) показано на рис. 1, на рис. 1, $a$ проілюстровано той факт, що із підвищенням температури сила тертя зменшується. Розглянемо детальніше криву 2. Спочатку при підвищенні температури надлишковий об'єм монотонно зростає. При цьому ефективний модуль зсуву $2 \mu_{\mathrm{eff}}(6)$ зменшується, що приводить до зниження значення пружної компоненти зсувних напружень (5) i, відповідно, до зменшення значення сили тертя (25). При перевищенні температурою критичного значення $T_{e}>T_{c 0}$, величина надлишкового об'єму $f$ стрибкоподібно збільшується і мастило плавиться, що приводить до різкого зниження повної сили тертя. 3 подальшим пониженням температури мастило твердне тепер уже при її меншому значенні $T_{e}=T_{c}^{0}$. При цьому залежність має гістерезисний характер, що відповідає фазовим переходам першого роду. Згідно з рис. 1, $a$ з підвищенням швидкості зсуву мастило плавиться при меншому значенні температури. При швидкості, вищій за деяке критичне значення, мастило незалежно від температури завжди рідиноподібне (крива 4) і сила тертя зменшується разом з температурою за рахунок зменшення модуля зсуву (розрідження мастила).

Таким чином, при малих температурах $\left(T_{e}<T_{c}^{0}\right)$ реалізується один мінімум потенціалу $\Phi(f)$, який відповідає стаціонарному стану 3 малим значенням $f$ (твердоподібне мастило). В області температур $T_{c}^{0}<$ $T_{e}<T_{c 0}$ співіснують два мінімуми $\Phi(f)$. Проте система не може перейти у стан, що відповідає другому мінімуму, оскільки ці мінімуми розділяє максимум енергії. За подальшого збільшення температури $T_{e}>T_{c 0}$ розмежовуючий максимум зникає, і мастило за механізмом фазового перетворення першого роду 

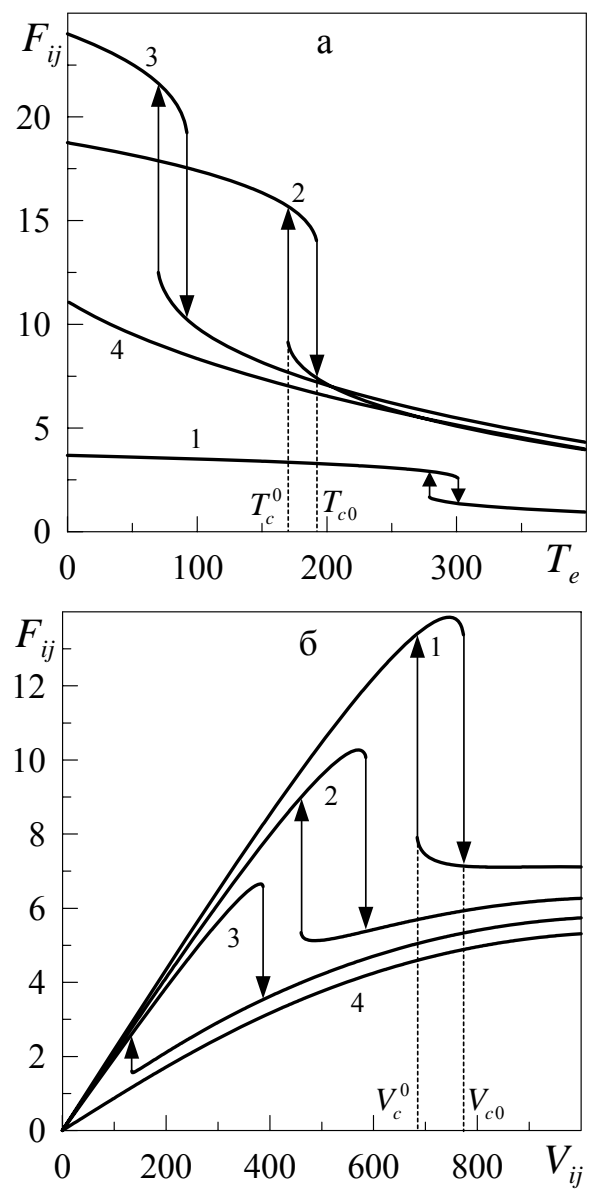

Рис. 1. Залежність стаціонарного значення повної сили тертя $F_{i j}(\mathrm{MH})(25)$ від температури поверхонь тертя $T_{e}(\mathrm{~K})$ і швидкості зсуву $V_{i j}\left(\right.$ нм $/$ с) при $\gamma=2 / 3, A=3 \cdot 10^{-9} \mathrm{~m}^{2}, n=-7 \cdot 10^{5}$ Па: $a$ - криві 1-4 відповідають сталим значенням швидкості зсуву $V_{i j}=150 \mathrm{нм} / \mathrm{c}, 800 \mathrm{нм} / \mathrm{c}, 1100 \mathrm{нм} / \mathrm{c}, 1400 \mathrm{нм} / \mathrm{c} ; б-$ криві $1-4$ відповідають фіксованим значенням температури $T_{e}=200 \mathrm{~K}$, $245 \mathrm{~K}, 279 \mathrm{~K}, 310 \mathrm{~K}$

переходить у стан, що відповідає єдиному мінімуму при великому значенні $f$, тобто плавиться. Якщо після цього знижувати температуру, то з появою першого мінімуму система знову не зможе перейти у відповідаючий йому стан внаслідок наявності розмежовуючого максимуму. 3 його зникненням при $T_{e}=T_{c}^{0}$ мастило стрибкоподібно твердне.

На рис. 1,б продемонстровано дещо іншу поведінку. Тут, згідно з (25), при малих швидкостях зсуву мастило твердоподібне, і відповідне значення $\sigma_{i j}^{\mathrm{e}}$ велике. Підвищення швидкості в такому режимі приводить до зростання обох компонент сили тертя (25), і тому вона швидко збільшується. При подальшому підвищенні швидкості мастило плавиться і пружне зсувне

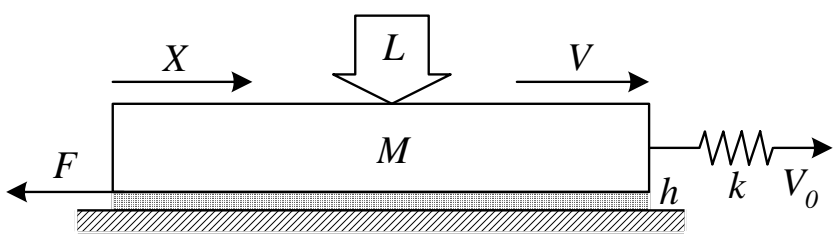

Рис. 2. Схема трибологічної системи

напруження (5) істотно зменшується, що, в свою чергу, приводить до різкого зниження повної сили тертя. 3 подальшим збільшенням швидкості значення $F_{i j}$ зростає за рахунок обох компонент сили тертя, які ростуть із швидкістю зсуву. Згідно з кривою 4 в рідиноподібному стані сила тертя (25) також зростає за рахунок збільшення швидкості. Тобто реалізується ситуація, схожа з поведінкою системи при підвищенні температури (рис. 1,a), з тією відмінністю, що у випадку зсувного плавлення із збільшенням температури поверхонь тертя зростає площа фігури, яку обмежує гістерезис. 3 підвищенням температури мастило плавиться при менших швидкостях зсуву. Зазначимо, що результати, які подано на рис. $1, \sigma$, якісно збігаються з новою картою тертя для межового режиму, запропонованою в роботі [39] в результаті узагальнення експериментальних даних. Залежності сили тертя від температури, типу поданих на рис. $1, a$, нині експериментально не вимірюються.

\section{4. Переривчастий режим}

Подані на рис. 1 залежності отримано за фіксованої швидкості зсуву верхньої поверхні тертя. Проте динамічні характеристики трибологічної системи визначаються не тільки силою тертя, наведеною на вказаному рисунку, а також і властивостями системи в цілому. Зокрема, згідно з експериментами, в області гістерезису залежності на рис. 1 можлива реалізація переривчастого режиму тертя (stick-slip) $[2,6,9,10,12,23,36,39]$, з'ясуванню особливостей якого присвячено цю роботу. Типову схему трибологічної системи подано на рис. 2. На схемі пружину із жорсткістю $k$ пов'язано з блоком масою $M$, до якого прикладено додаткове навантаження $L$. Блок розташований на гладкій поверхні, від якої відокремлений шаром мастила товщиною $h$. Вільний кінець пружини приводиться в рух з сталою швидкістю $V_{0}$. При русі блока виникає сила тертя $F(25)$, що чинить опір його пересуванню. Для ультратонких шарів змащувальних матеріалів у режимі межового тертя швидкості блока $V$ і пружини $V_{0}$ можуть не збігатися внаслідок осцилюючого характеру сили $F$, що приводить 
до переривчастого руху блока. Даний режим нагадує сухе тертя без мастила.

Рівняння руху верхнього блока має вигляд $[2,4,6]:^{4}$

$M \ddot{X}=k\left(\int_{0}^{t} V_{0} d t^{\prime}-X\right)-F$,

де $t=t^{\prime}$ - час руху. У випадку сталого значення швидкості зсуву $V_{0}$ інтеграл у $(26)$, зазвичай, можна замінити виразом $V_{0} t$. Для обчислення часової еволюції сили тертя останнє рівняння необхідно розв'язувати разом з (11), (14), (18), визначаючи при цьому силу тертя з (25). Проте часи релаксації деформації $\tau_{\varepsilon}$ і ентропії $\tau_{s}=h^{2} / \kappa$ за рахунок тонкості мастила, можна покласти малими у порівнянні з часом релаксації надлишкового об'єму $\tau_{f}$. Тому, в межах наближення $\tau_{f} \gg \tau_{\varepsilon}, \tau_{s}$, розв'язуватимемо спільно два рівняння (26), (11), визначаючи температуру і деформацію 3 (19), а ентропію з (12).

Результат розв'язку вказаних рівнянь наведено на рис. 3. Згідно з останнім сила тертя спочатку монотонно зростає, оскільки мастило твердоподібне, а швидкість зсуву збільшується. Коли вона перевищує критичне значення $V_{c 0}$, мастило плавиться, за рахунок чого зменшується сила тертя, росте швидкість руху верхнього блока $V$ і він швидко переміщується на велику відстань. При цьому зменшується натягнення пружини i, відповідно, швидкість зсуву. Коли вона стає меншою за значення, що необхідне для підтримки мастила в рідиноподібному стані, останнє твердне, і сила тертя починає зростати. Описаний процес періодично повторюється у часі. Зазначимо, що швидкість, при якій мастило твердне, не збігається з аналогічною швидкістю, наведеною на рис. 1. Це пов'язано з різким збільшенням швидкості зсуву $V$ при плавленні і відповідним збільшенням параметра $f$. Згідно з (6) модуль зсуву при цьому стає меншим за нуль і його необхідно вважати за нульовий, що змінює вигляд потенціалу (1). При цьому за наявності пружних деформацій (18) пружні напруження в мастилі згідно з (5) стають нульовими, що і зумовлює зниження сили тертя, а мастило при цьому тече.

На рис. 4 показано залежність повної сили тертя $F(25)$, надлишкового об'єму $f$ і пружної компоненти зсувних напружень $\sigma_{i j}^{\mathrm{e}}(5)$ від часу при збільшенні швидкості зсуву $V_{0}$. Спочатку рух верхнього зрушуваного блока $\left(V_{0}=V_{01}\right)$ приводить до зростання надлишкового об'єму $f$. Коли $f$ досягає критичного

\footnotetext{
4 Оскільки розглядається зсув в одному напрямку, далі для зручності запису опускатимемо тензорні позначення.
}

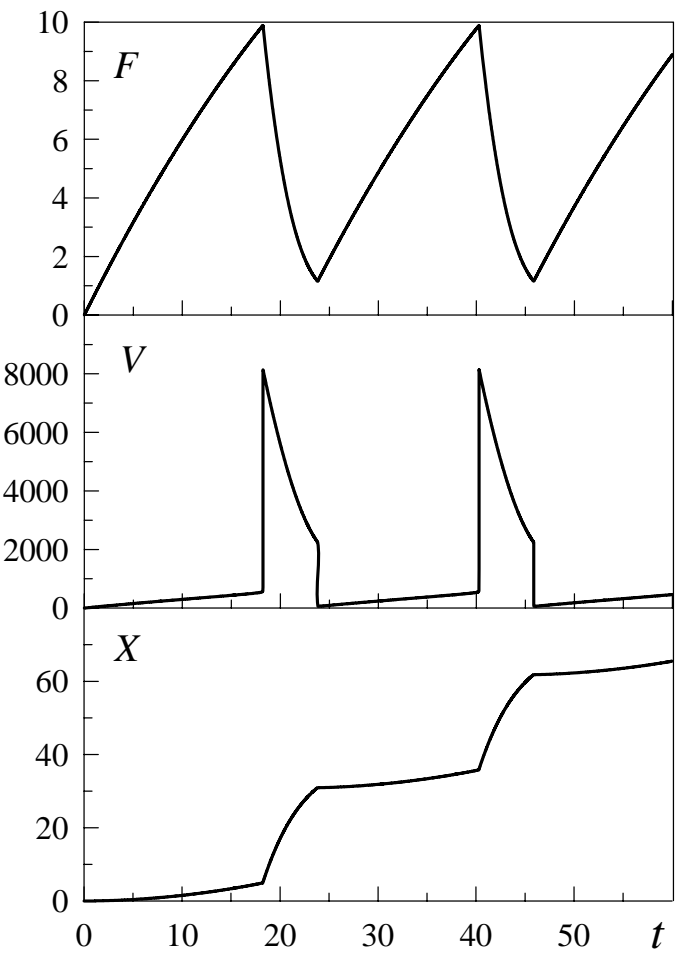

Рис. 3. Залежність сили тертя $F(\mathrm{mH})$, швидкості зсуву поверхні тертя $V($ нм/с) та її координати $X$ (мкм) від часу $t$ (c) при параметрах $n=-7 \cdot 10^{5}$ Па, $M=0,4$ кг, $k=480 \mathrm{H} / \mathrm{M}$, $T_{e}=250 \mathrm{~K}, V_{0}=1400 \mathrm{HM} / \mathrm{c}$

значення, мастило плавиться за механізмом фазового перетворення першого роду, при цьому параметр $f$ стрибкоподібно збільшується. Мастило після цього знову починає тверднути, оскільки зменшується відносна швидкість зсуву поверхонь тертя (див. рис. 3). Після повного тверднення в ньому з'являється пружне напруження, подальше зростання якого знову приводить до збільшення параметра $f$, поки той досягне критичного значення, необхідного для плавлення, і процес повторюється знову. У результаті встановлюється періодичний переривчастий (stick-slip) режим плавлення/тверднення. При підвищенні швидкості до значення $V_{0}=V_{02}$ частота stick-slip піків збільшується за рахунок того, що при цій швидкості у системі швидше встановлюється критичне значення $f$. Відповідно, мастило швидше плавиться, а тому за один і той же проміжок часу система встигає зробити більшу кількість переходів плавлення/тверднення. 3 подальшим збільшенням швидкості $V_{0}=V_{03}$ частота stick-slip піків знову зменшується. Це відбувається за рахунок того, що на залежності $F(t)$ з'являються довгі кінетичні ділянки $F=$ const. Слід зазначити, що в цьому режимі параметр $f$ при плавленні спочатку 


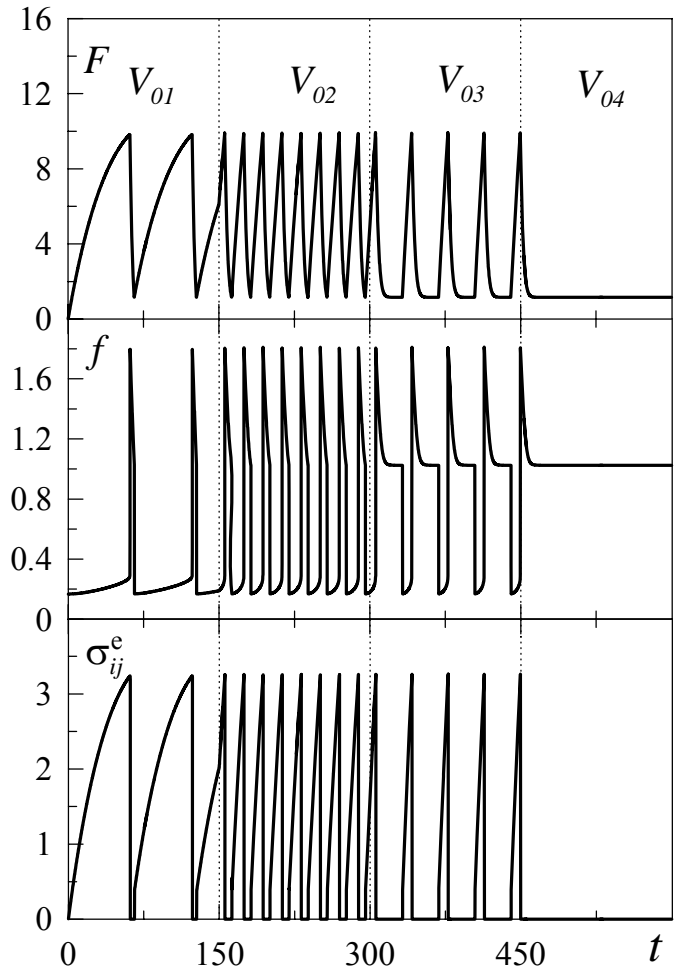

Рис. 4. Залежність сили тертя $F$ (мН), надлишкового об'єму $f$ і пружної компоненти напружень $\sigma_{i j}^{\mathrm{e}}(\mathrm{MПа)} \mathrm{від} \mathrm{часу} t(\mathrm{c})$ при параметрах рис. 3 і швидкостях зсуву $V_{01}=650 \mathrm{Hм} / \mathrm{c}$, $V_{02}=1800 \mathrm{Hм} / \mathrm{c}, V_{03}=2246,7 \mathrm{Hм} / \mathrm{c}, V_{04}=2247 \mathrm{Hм} / \mathrm{c}$

різко зростає завдяки швидкому збільшенню швидкості зсуву верхнього блока $V$. Стаціонарній кінетичній ділянці відповідає менше значення надлишкового об'єму $f$, що встановлюється після різкого початкового зсуву верхньої поверхні, що треться, за рахунок вивільнення частини механічної потенціальної енергї розтиснутої пружини. За подальшого зростання швидкості $V_{0}=V_{04}$ переривчастий режим зникає і встановлюється кінетичний режим тертя рідиноподібного мастила, що характеризується більшим значенням надлишкового об'єму $f$ та нульовими пружними зсувними напруженнями $\sigma_{i j}^{\mathrm{e}}$. Зазначимо, що рідиноподібний стан не завжди характеризується нульовим значенням напружень $\sigma_{i j}^{\mathrm{e}}[5]$, і в даному випадку цей факт зумовлений рівністю ефективного модуля зсуву мастила (6) нулю в рідиноподібному стані [4]. Таким чином, при збільшенні швидкості частота stick-slip піків спочатку збільшується, а потім зменшується за рахунок появи довгих кінетичних ділянок. При перевищенні критичного значення швидкості $V_{0}$ режим stick-slip зникає. Описана поведінка добре узгоджується з експериментальними даними [2].

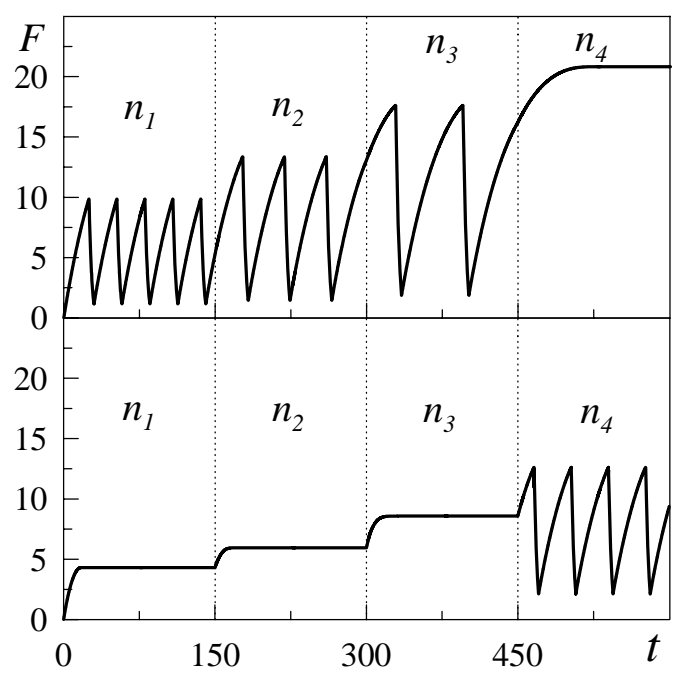

Рис. 5. Залежність сили тертя $F(\mathrm{mH})$ від часу $t$ (c) при параметрах рис. 3 i зовнішньому нормальному навантаженні: $n_{1}=-7 \cdot 10^{5} \Pi \mathrm{a}, n_{2}=-50 \cdot 10^{5}$ Па, $n_{3}=-80 \cdot 10^{5}$ Па, $n_{4}=-100 \cdot 10^{5}$ Па. Верхня панель відповідає температурі $T_{e}=250 \mathrm{~K}$, нижня $-T_{e}=400 \mathrm{~K}$

У експериментах також часто досліджується вплив на характер плавлення мастила зовнішнього нормального тиску, що прикладений до поверхонь тертя $[2,36]$. Такі експерименти показують, що тиск впливає на параметри трибологічної системи нетривіально. Наприклад, для мастил з ланцюгових молекул гексадекана зі зростанням тиску критична швидкість зсуву зменшується, а для квазісферичних молекул ОМЦТС вона навпаки збільшується [2]. Тиск також впливає на частоту і амплітуду stick-slip переходів [2]. В межах нашої моделі згідно з рівнянням (11) зростання навантаження на поверхні тертя приводить до зменшення надлишкового об'єму, що повинно сприяти твердненню мастила.

На рис. 5 подано часову залежність сили тертя при різних значеннях нормального тиску, дію якого направлено на стиснення поверхонь тертя. При температурі, нижчій за критичне значення (верхня панель рисунка), реалізується переривчастий режим тертя. Причому, із зростанням тиску збільшується амплітуда stick-slip переходів та значення кінетичної i статичної сил тертя, а також зменшується частота переходів. При тиску, що відповідає нормальному напруженню $n=n_{4}$, stick-slip режим не реалізується. Проте, при цьому встановлюється не кінетичний режим, що відповідає рідиноподібному мастилу, а відбувається тверднення мастила внаслідок стиснення стінок. За рахунок цього мастило вже не може розплавитися, тому встановлюється велике зна- 
чення сили тертя $F$, що відповідає твердоподібному мастилу і малому значенню надлишкового об'єму $f$, оскільки стиснення стінок сприяє виникненню в мастилі дальнього порядку чергування атомів. На нижній панелі рисунка подано залежність, яка наявна при підвищеній температурі поверхонь тертя $T_{e}$. Тут видно, що встановлюється кінетичний режим тертя, який відповідає малому значенню сили тертя і великому значенню надлишкового об'єму $f$. Проте, при $n=n_{4}$ наступає stick-slip режим, оскільки при такому значенні нормального напруження $n$ згідно з рівнянням (11) мастило вже не може бути завжди рідиноподібним. 3 подальшим зростанням тиску слід чекати повного тверднення мастила, див. верхню панель рисунка, при $n=n_{4}$. Таким чином, виявлено три режими тертя: 1) кінетичний режим, в якому мастило завжди рідиноподібне; 2) переривчастий режим, що відповідає періодичному плавленню/твердненню; 3) режим сухого тертя, що характеризується великим значенням сили тертя і твердоподібною структурою мастила. Ці режими знайдено також у роботі [9] в межах стохастичної моделі.

На рис. 6 подано залежність сили тертя від часу при підвищенні температури поверхонь тертя, яка в даному розгляді збігається з температурою мастила. Видно, що підвищення температури приводить до зниження амплітуди коливань сили тертя і збільшення частоти фазових переходів рідиноподібне - твердоподібне мастило. При $T_{e}=T_{e 4}$ наступає режим ковзання, що характеризується сталим значенням кінетичної сили тертя і незмінною швидкістю зсуву верхнього блока. Таким чином, підвищення температури сприяє плавленню мастила. Дана залежність є прогнозуючою, оскільки експерименти з подібним дослідженням впливу температури нам невідомі.

\section{5. Висновки}

Запропонована теорія дозволяє описати ефекти, що спостерігаються при плавленні ультратонкої плівки мастила в режимі межового тертя. Проведено узгоджений розгляд термодинамічного і зсувного плавлення. Розглянуто залежність сили тертя від швидкості зсуву і температури. При високій температурі поверхонь тертя зсувне плавлення наступає при меншому значенні швидкості зсуву (зсувних напружень), а за подальшого збільшення температури мастило плавиться навіть при нульовій швидкості зсуву. У моделі враховано вплив температури, зсувне плавлення i

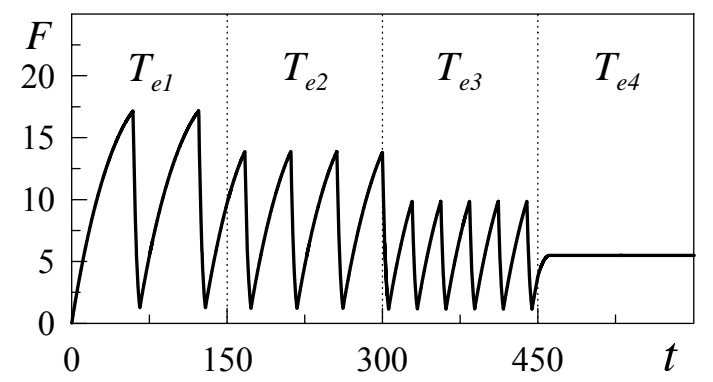

Рис. 6. Залежність сили тертя $F(\mathrm{mH})$ від часу $t$ (c) при параметрах рис. 3 і температурі поверхонь тертя $T_{e 1}=150 \mathrm{~K}$, $T_{e 2}=200 \mathrm{~K}, T_{e 3}=250 \mathrm{~K}, T_{e 4}=300 \mathrm{~K}$

зовнішній тиск. Це головні чинники, що вивчаються експериментально.

В межах запропонованої теорії досліджено просту трибологічну систему і отримано часові залежності сили тертя при підвищенні швидкості зсуву, тиску і температури. Показано, що в системі в широкому діапазоні параметрів реалізується переривчастий режим тертя, який спостерігається експериментально. 3'ясовано, що тиск впливає на систему нетривіально. Отримані результати якісно збігаються з відомими експериментальними даними. Оскільки модель є кількісною, її модифікації можуть використовуватися для опису конкретних експериментів.

Автори вдячні Державному фонду фундаментальних досліджень України та Російському фонду фундаментальних досліджень (грант Ф28/443-2009) за підтримку роботи.

1. B.N.J. Persson, Sliding Friction. Physical Principles and Applications (Springer-Verlag, Berlin, 1998).

2. H. Yoshizawa, Y.-L. Chen, and J. Israelachvili, J. Phys. Chem. 97, 4128 (1993); H. Yoshizawa and J. Israelachvili, J. Phys. Chem. 97, 11300 (1993).

3. E.D. Smith, M.O. Robbins, and M. Cieplak, Phys. Rev. B 54, 8252 (1996).

4. В.Л. Попов, ЖТФ 71, 100 (2001).

5. Я.А. Ляшенко, А.В. Хоменко, Л.С. Метлов, ЖТФ 80, 120 (2010).

6. J.M. Carlson and A.A. Batista, Phys. Rev. E 53, 4153 (1996).

7. A.V. Khomenko and O.V. Yushchenko, Phys. Rev. E 68, 036110 (2003).

8. A.V. Khomenko and I.A. Lyashenko, Condens. Matter Phys. 9, 695 (2006).

9. A.E. Filippov, J. Klafter, and M. Urbakh, Phys. Rev. Lett. 92, 135503 (2004). 
10. Z. Tshiprut, A.E. Filippov, and M. Urbakh, Phys. Rev. Lett. 95, 016101 (2005).

11. А.В. Хоменко, Я.А. Ляшенко, Трение и износ. 31, 412 (2010).

12. O.M. Braun and A.G. Naumovets, Surf. Sci. Rep. 60, 79 (2006).

13. A.V. Khomenko and N.V. Prodanov, Condens. Matter Phys. 11, 615 (2008).

14. A.V. Khomenko and N.V. Prodanov, Carbon 48, 1234 (2010).

15. R.G. Horn, D.T. Smith, and W. Haller, Chem. Phys. Lett. 162, 404 (1989).

16. А.В. Хоменко, Я.А. Ляшенко, ЖТФ 75, 17 (2005).

17. А.В. Хоменко, Я.А. Ляшенко, ЖТФ 77, 137 (2007).

18. A.V. Khomenko and I.A. Lyashenko, Fluct. Noise Lett. 7, L111 (2007).

19. О.В. Хоменко, Я.О. Ляшенко, В.М. Борисюк, УФЖ 54, 1142 (2009).

20. A.V. Khomenko, I.A. Lyashenko, and V.N. Borisyuk, Fluct. Noise Lett. 9, 19 (2010).

21. A.L. Demirel and S. Granick, J. Chem. Phys. 109, 6889 (1998).

22. G. Reiter, A.L. Demirel, J. Peanasky, L.L. Cai, and S. Granick, J. Chem. Phys. 101, 2606 (1994).

23. J. Israelachvili, Surf. Sci. Rep. 14, 109 (1992).

24. О.В. Хоменко, Я.О. Ляшенко, Журн. фіз. досл. 11, 268 (2007).

25. А.В. Хоменко, Я.А. Ляшенко, ФТТ 49, 886 (2007).

26. A.V. Khomenko and I.A. Lyashenko, Phys. Lett. A 366, 165 (2007).

27. А.В. Хоменко, Я.А. Ляшенко, ЖТФ 80, 27 (2010).

28. A. Lemaître and J. Carlson, Phys. Rev. E 69, 061611 (2004).

29. A. Lemaître, Phys. Rev. Lett. 89, 195503 (2002).

30. Л.С. Метлов, М.М. Мышляев, ДАН 433, 477 (2010).

31. L.S. Metlov, Phys. Rev. E 81, 051121 (2010).

32. Л.С. Метлов, Изв. РАН. Сер. Физ. 72, 1353 (2008).

33. Л.С. Метлов, Металлофиз. новейш. технол. 29, 335 (2007).

34. А.В. Хоменко, Я.А. Ляшенко, Л.С. Метлов, Металлофиз. новейш. технол. 30, 859 (2008).

35. P.A. Thompson, G.S. Grest, and M.O. Robbins, Phys. Rev. Lett. 68, 3448 (1992).

36. M.L. Gee, P.M. McGuiggan, and J.N. Israelachvili, J. Chem. Phys. 93, 1895 (1990).

37. Л.М. Качанов, Основъ теории пластичности (Наука, Москва, 1969).

38. Л.Д. Ландау, Е.М. Лифшиц, Теория упругости (URSS, Москва, 2003).
39. G. Luengo, J. Israelachvili, S. Granick, Wear 200, 328 (1996).

40. И.Н. Евдокимов, Н.Ю. Елисеев, Молекулярные механизмы вязкости жидкости и газа. Ч. 1. Основные понятия (РГУ нефти и газа им. И. М. Губкина, Москва, 2005).

Одержано 12.09.10

\section{ФЕНОМЕНОЛОГИЧЕСКАЯ ТЕОРИЯ ПРЕРЫВИСТОГО} РЕЖИМА ГРАНИЧНОГО ТРЕНИЯ

Я.А. Ляшенко, А.В. Хоменко, Л.С. Метлов

Р е $з$ ю м е

Построена детерминистическая теория плавления ультратонкой пленки смазки, зажатой между двумя атомарно-гладкими твердыми поверхностями. Для описания состояния смазки введен параметр избыточного объема, который возникает за счет хаотизации структуры твердого тела в процессе плавления. Сoгласованным образом описано термодинамическое и сдвиговое плавление. Проанализированы зависимости стационарной силы трения от температуры смазки и скорости сдвига трущихся поверхностей при их равномерном движении с постоянной скоростью. В рамках простой трибологической модели описан прерывистый режим трения, при котором смазка периодически плавится и затвердевает. Проанализировано влияние скорости, температуры и нагрузки на прерывистое трение. Проведено качественное сравнение полученных результатов с экспериментальными данными.

\section{PHENOMENOLOGICAL THEORY OF BOUNDARY} FRICTION IN THE STICK-SLIP MODE

I.A. Lyashenko ${ }^{1}$, A.V. Khomenko ${ }^{1}$, L.S. Metlov ${ }^{2}$

${ }^{1}$ Sumy State University

(2, Rimskii-Korsakov Str., Sumy 40007, Ukraine; e-mails: nabla04@ukr.net, khom@mss.sumdu.edu.ua)

${ }^{2}$ A.A. Galkin Donetsk Institute for Physics and Engineering, Nat. Acad. of Sci. of Ukraine

(72, R. Luxemburg Str., Donetsk 83114, Ukraine;

e-mail: lsmet@fti.dn.ua)

S u m m a r y

A deterministic theory describing the melting of an ultrathin lubricant film between two atomically smooth solid surfaces has been developed. The lubricant state is described by introducing a parameter of excess volume that arises owing to the solid structure chaotization at its melting. The thermodynamic and shear kinds of melting are described consistently. The dependences of the stationary friction force on the lubricant temperature and the shear velocity of rubbing surfaces that move with respect to each other with a constant velocity have been analyzed. In the framework of a simple tribological model, the stick-slip mode of friction, when the lubricant periodically melts and solidifies, has been described. The influence of velocity, temperature, and load on the stick-slip friction has been analyzed. A qualitative comparison between the results obtained and experimental data has been carried out. 